\title{
Efektifitas Zakat Produktif Dalam Memberdayakan UMKM (Studi Kasus Pelaku UMKM di Pedan, Klaten, Jawa Tengah)
}

\author{
M Usman ${ }^{1 *}$, Nur Sholikin ${ }^{2)}$ \\ ${ }^{1,2}$ Program Pascasarjana, IAIN Surakarta \\ *Email korespondensi: nur9sholikin@ gmail.com
}

\begin{abstract}
Productive zakat is zakat given to a person or group of people to be used as working capital. Giving productive zakat to mustahik MSME actors is expected to help increase Mustahik's income so that it can reduce poverty levels. Productive zakat distribution at Baznas is expected to be able to alleviate poverty in society. In 2018, Pedan District was one of the areas selected by Baznas in distributing productive zakat to MSME players. This sub-district is located in Klaten Regency which has a position as one of the development centers of Klaten Regency. The majority of Pedan people work as MSME actors, so that if the potential of this community can be maximized it will reduce the level of poverty in the area. This research is a field research (field research). To achieve this goal the writer uses a qualitative descriptive approach. In this study, primary data was generated from interviews with mustahik who received assistance from Baznas. Meanwhile, secondary data is obtained from books, journals and related laws and regulations. The results showed that the distribution of productive zakat at Baznas to MSME players in Pedan has had a positive impact on increasing their business results as seen from the amount of mustahik income before and after receiving productive zakat calculated from the total net income of MSMEs after receiving assistance from Baznas, return or net profit received by mustahik in 2018 and 2019, the final capital analysis is calculated after the total liabilities and equity of MSME businesses, the level of capital growth (Pedan people) before and after receiving productive zakat
\end{abstract}

Keywords: Productive Zakat, Baznas, UMKM.

Saran sitasi: Usman, M., \& Sholikin, N. (2021). Efektifitas Zakat Produktif Dalam Memberdayakan UMKM (Studi Kasus Pelaku UMKM di Pedan, Klaten, Jawa Tengah). Jurnal Ilmiah Ekonomi Islam, 7(01), 174-182. doi:http://dx.doi.org/10.29040/jiei.v7i1.1599

DOI: http://dx.doi.org/10.29040/jiei.v7i1.1599

\section{PENDAHULUAN}

Kemiskinan merupakan salah satu problem utama dalam pembangunan bangsa. Integrasi program penurunan tingkat kemiskinan telah menjadi bagian dari agenda pembangunan nasional sejak negeri ini merdeka (Departemen Ekonomi Dan Keuangan Syariah -Bank Indonesia, 2016: 5). Berdasarkan data BPS, tingkat kemiskinan di Indonesia secara umum selalu menurun. Pada bulan Maret 2018, jumlah penduduk miskin (penduduk dengan pengeluaran perkapita per-bulan dibawah garis kemiskinan) di Indonesia mencapai 25,95 juta orang ( 9,82 persen), berkurang sebesar 633,2 ribu orang yang dibandingkan dengan kondisi September 2017 yang sebesar 26,58 juta orang (10,12 persen) (Badan Pusat Statistik, 2018).
Kemiskinan yang terjadi di Indonesia salah satunya diakibatkan karena kurangnya masyarakat miskin untuk mendapatkan modal usaha. Lembagalembaga keuangan sebagai lembaga intermediasi yang menyalurkan dana dari masyarakat yang surplus dana kepada masyarakat yang devisit dana tidak menjalankan fungsinya dengan baik. Ini terlihat dari banyaknya masyarakat yang unbankable, karena mereka tidak mempunyai aset untuk agunan sebagai dasar pinjaman kredit, dan minimnya skill kewirausahaan juga mengakibatkan susahnya masyarakat miskin untuk lepas dari kemiskinannya. Oleh karena itu dibutuhkan satu metode dan instrumen yang bisa memberdayakan masyarakat miskin, dan memberikan kemudahan masyarakat miskin untuk mendapatkan akses modal untuk berusaha. Salah satu instrument tersebut adalah zakat (Pratama, 2015: 94). 


\section{Jurnal Ilmiah Ekonomi Islam, 7(01), 2021, 175}

Menurut Dr. Yusuf Qardhawi, mengoptimalkan pelaksanaan zakat dapat mengentaskan atau memperkecil masalah kemiskinan. Hal itu dikarenakan zakat adalah sumber dana yang tidak akan pernah kering dan habis. Dengan kata lain selama umat Islam memiliki kesadaran untuk berzakat dan selama dana zakat tersebut mampu dikelola dengan baik, maka dana zakat akan selalu ada serta bermanfaat untuk kepentingan dan kesejahteraan masyarakat (Qardhawi, 2002: 45).

Zakat bagi umat Islam sudah diyakini sebagai pokok ajaran Islam yang harus ditunaikan. Zakat merupakan rukun Islam yang ketiga setelah sholat. Melaksanakannya wajib, dengan begitu telah dipandang sebagai dosa bagi siapa yang meninggalkannya dan sebaliknya akan mendapatkan pahala bagi yang menjalankannya (Hafiduddin, 2007: $1)$.

Potensi zakat ini jika digarap dengan baik, akan menjadi sumber pendanaan yang sangat besar, sehingga dapat menjadi kekuatan pendorong pemberdayaan ekonomi umat dan pemerataan pendapatan (Edwin, 2007: 211). Menurut Hafidhuddin pengelolaan zakat sudah dilakukan semenjak awal Islam masuk dan berkembang, baik oleh individu maupun kelompok atau institusi tertentu. Namun demikian, mayoritas ulama di dunia dan Indonesia sepakat bahwa sebaiknya pengelolaan zakat dilakukan oleh pemerintah. Pengelolaan oleh lembaga formal diharapkan dapat meningkatkan efektivitas pengumpulan dan pengalokasian dana zakat untuk mencapai sasaran yang ditargetkan. Salah satu bentuk upaya pemerintah Indonesia dalam melembagakan pengelolaan zakat adalah dibentuknya Badan Amil Zakat Nasional (Baznas) (Pratama, 2015: 95).

Dalam menyalurkan dana ZIS, Baznas akan melihat daerah yang dirasa cukup membutuhkan bantuan guna memajukan perekonomian daerah tersebut. Salah satu daerah yang dipilih oleh Baznas untuk diberikan modal usaha adalah di Kecamatan Pedan, Kabupaten Klaten, Provinsi Jawa Tengah.

Kecamatan Pedan merupakan salah satu kecamatan yang terletak di Kabupaten Klaten yang mempunyai kedudukan sebagai salah satu pusat pengembangan Kabupaten Klaten yang mempunyai potensi dalam bidang perekonomian industri, transportasi serta mempunyai tingkat aksesbilitas yang sangat mendukung bagi perkembangan maupun pengembangan Kecamatan Pedan (Badan Pusat Statistik Kecamatan Pedan, 2018).

Ketersediaan fasilitas sosial ekonomi yang terdapat di Kecamatan Pedan merupakan faktor pendorong bagi pertumbuhan perekonomian di wilayah ini. Fasilitas sosial antara lain terdiri dari fasilitas pendidikan dan kesehatan. Fasilitas pendidikan dan kesehatan dapat menunjukkan kualitas sumber daya manusia. Sedangkan perdagangan dan jasa digunakan untuk memperkirakan kinerja dan dinamika sektor-sektor ekonomi wilayah tersebut. Kelebihan Kecamatan Pedan adalah apabila kecamatan ini dikelola dengan baik akan dapat dikembangkan potensinya. Hal ini dikarenakan Daerah ini merupakan sektor pusat perdagangan, Daerah ini mempunyai tingkat pertumbuhan ekonomi paling tinggi yang disusul oleh Kecamatan Trucuk, Bayat dan Cawas (Badan Pusat Statistik Kecamatan Pedan, 2018).

Daerah ini terletak di jalan yang strategis karena berada pada daerah peralihan antara desa dan peralihan desa ke kota yaitu Kecamatan Ceper yang sebagian besar berada pada jalan lalu lintas ramai. Ketersediaan fasilitas ekonomi yang ada di Kecamatan Pedan adalah pasar, toko, kios, Bank (Syariah/Konvensional), dan BPR (Syariah/Konvensional) (Badan Pusat Statistik Kecamatan Pedan, 2018).

Mayoritas masyarakat Pedan berprofesi sebagai padagang. Ditengah potensi yang dirasa cukup besar untuk pengembangan usaha masyarakat, beberapa diantaranya ada masyarakat miskin yang membutuhkan sentuhan dari pemerintah ataupun lembaga lain yang dirasa dapat memberikan suntikan modal serta pendampingan guna pengembangan usaha mereka.

Pada tahun 2018, Baznas telah berperan dalam memberikan bantuan sebesar 5 juta Rupiah kepada para pelaku UMKM di Kecamatan Pedan yang mempunyai produk atau lahan usaha yang membutuhkan modal agar produk atau usaha yang mereka geluti dapat bersaing dan mempunyai nilai tambah bagi kehidupan mereka. Dengan jumlah total 31 orang yang telah menerima bantuan dana diharapkan dapat menjadi contoh bagi pelaku usaha yang lain dalam menggeluti bidang usahanya masingmasing. Beberapa jenis usaha yang mereka geluti diantaranya adalah usaha makanan/ kuliner, asesoris/ fashion, jasa dan peternakan. 


\section{Jurnal Ilmiah Ekonomi Islam, 7(01), 2021, 176}

Untuk melihat efektivitas pemberian modal usaha kepada mustahik, maka diperlukan penelitian terkait perkembangan usaha dan jumlah pendapatan mustahik untuk mengukur keberhasilan kinerja Baznas. Disini penulis mengkaji efektivitas implementasi zakat produktif untuk pemberian modal usaha kepada mustahik pelaku UMKM yang akan dilihat dari tingkat pendapatan mustahik sebelum dan sesudah menerima zakat produktif.

\section{METODE PENELITIAN}

Penelitian ini merupakan penelitian lapangan (field research). Untuk mencapai tujuan tersebut penulis menggunakan pendekatan kualitatif yang bersifat deskriptif. Dalam penelitian ini, data primer dihasilkan dari wawancara dengan mustahik yang menerima bantuan dari Baznas. Sedangkan data sekunder diperoleh dari buku-buku, jurnal dan peraturan perundang-undangan yang terkait.

Pengumpulan data dilakukan dengan teknik dokumentasi, sedangkan wawancara dilakukam secara terstruktur dengan menggunakan pedoman wawancara serta proses wawancara dilakukan dengan meminta izin terlebih dahulu kepada calon partisipan. Penulis menjelaskan maksud wawancara adalah untuk menghimpun dan mengumpulkan data-data yang diperlukan yang kemudian akan dianalisis.

\section{HASIL DAN PEMBAHASAN}

Zakat produktif adalah zakat diberikan kepada seseorang atau kelompok masyarakat untuk digunakan sebagai modal kerja (Raharjo, 1999: 45). Disyaratkan bahwa yang berhak memberikan zakat yang bersifat produktif adalah yang mampu melakukan pembinaan dan pendampingan kepada para mustahik agar kegiatan usahanya dapat berjalan dengan baik. Disamping melakukan pembinaan dan pendampingan kepada para mustahik dalam kegiatan usahanya, juga harus memberikan pembinaan ruhani dan intelektual keagamaannya agar semakin meningkat kualitas keimanan dan keIslamannya.

Hukum zakat produktif adalah boleh bahkan sangat dianjurkan bila dikaitkan dengan kondisi negara Indonesia saat ini. Agar dari zakat produktif tersebut, masyarakat mampu berorientasi dan berbudaya produktif, sehingga dapat memproduksi sesuatu yang dapat menjamin kebutuhan hidup mereka sehingga diharapkan dapat mengurangi bahkan mengentaskan kemiskinan (Asnaini, 2008: 93).
Pengentasan kemiskinan membutuhkan jalan panjang yang dapat ditempuh dalam dua langkah dan pendekatan yaitu pendekatan parsial dan pendekatan struktural. Pendekatan parsial, yaitu dengan pemberian bantuan langsung berupa sedekah biasa dari orang-orang kaya dan dari dana zakat kepada yang betul-betul tidak produktif lagi (karena cacat jasmani dan rohani). Pendekatan struktural, yaitu pendekatan yang bertujuan untuk menuntaskan kemiskinan secara sistematis, berupa menghilangkan faktor-faktor penyebab kemiskinan itu sendiri, baik yang disebabkan oleh faktor internal maupun eksternal (Qadir, 1998: 223).

Baznas merupakan badan resmi satu-satunya yang dibentuk oleh pemerintah Indonesia berdasarkan Keputusan Presiden RI No. 8 Tahun 2001 yang memiliki tugas dan fungsi menghimpun dan menyalurkan zakat, infaq dan sedekah (ZIS) pada tingkat nasional. Lahirnya Undang-undang Nomor 23 Tahun 2011 Tentang Pengelolaan Zakat semakin mengukuhkan peran Baznas sebagai lembaga yang berwenang melakukan pengelolaan zakat secara nasional. (Profil BAZNAS, 2019). Baznas mempunyai peran dalam menyalurkan zakat kepada masyarakat. Tidak hanya secara konsumtif namun diharapkan dengan zakat tersebut masyarakat dapat meningkat perekonomiannya. Salah satu instrumen dari zakat produktif yaitu diberikan kepada para pelaku Usaha Mikro Kecil Menengah (UMKM).

Usaha mikro adalah usaha produktif milik orang perorangan dan/atau badan usaha perorangan yang memenuhi kriteria usaha mikro sebagaimana diatur dalam Undang-Undang Nomor 20 Tahun 2008. Usaha kecil adalah usaha ekonomi produktif yang berdiri sendiri, yang dilakukan oleh orang perorangan atau badan usaha yang bukan merupakan anak perusahaan atau bukan cabang perusahaan yang dimiliki, dikuasai, atau menjadi bagian baik langsung maupun tidak langsung dari usaha menengah atau usaha besar yang memenuhi kriteria usaha kecil. Adapun usaha menengah adalah usaha ekonomi produktif yang berdiri sendiri, yang dilakukan oleh orang perseorangan atau badan usaha yang bukan merupakan anak perusahaan atau cabang perusahaan yang dimiliki, dikuasai, atau menjadi bagian baik langsung maupun tidak langsung dengan usaha kecil atau usaha besar dengan jumlah kekayaan bersih atau hasil penjualan tahunan sebagaimana diatur dalam undang-undang ini (Sari, 2013: 193). 


\section{Jurnal Ilmiah Ekonomi Islam, 7(01), 2021, 177}

Pemberdayaan usaha mikro, kecil dan menengah (UMKM) merupakan langkah yang strategis dalam meningkatkan dan memperkuat dasar kehidupan perekonomian dari sebagian rakyat Indonesia, khususnya melalui penyediaan lapangan kerja serta mengurangi kesenjangan dan tingkat kemiskinan. Selain itu, peningkatan kualitas koperasi untuk berkembang secara sehat sesuai dengan jati dirinya dan membangun efisiensi kolektif terutama bagi pengusaha mikro dan kecil (Setiawan, 2012: 59).

Secara umum, masalah-masalah yang menjadi kendala dalam pengembangan UMKM adalah rendahnya produktivitas, terbatasnya akses kepada sumber daya produktif, rendahnya kualitas kelembagaan dan organisasi, serta kurang kondusifnya iklim usaha. Perkembangan UMKM juga ditandai oleh beberapa ciri yang bersifat klasik. Ciriciri tersebut adalah permodalan yang terbatas, skala pemasaran yang relatif sempit, manajemen yang tidak teratur, kualitas sumber daya manusia, bahan baku dan produk yang relatif rendah serta penggunaan teknologi yang juga rendah. Akan tetapi, masalah utama yang dihadapi oleh UMKM dalam perekonomian Indonesia adalah masalah yang bersifat struktural, yakni UMKM beroperasi dalam lingkungan dan struktur yang tidak adil dan diskriminatif (Retnandari, 2009: 28).

Pemberian bantuan modal untuk pengembangan UMKM merupakan usaha untuk meningkatkan pendapatan para pelaku UMKM, sehingga ekonomi keluarga terangkat. Pelaksanaan program tersebut memunculkan banyak kegiatan UMKM, di antaranya ada yang berwirausaha dalam bidang makanan/kuliner, asesoris/fashion, peternakan, jasa. Dengan pemberian modal tersebut, beberapa kelompok masyarakat juga memanfaatkan untuk pembiayaan membuka usaha baru.

Pada tahun 2018, Kecamatan Pedan merupakan salah satu daerah yang dipilih oleh Baznas untuk diberikan zakat produktif kepada para pelaku UMKM nya. Daerah ini dipilih karena mempunyai potensi yang bagus untuk diberdayakan sehingga diharapkan masyarakatnya dapat survive dan keluar dari zona kemiskinan. Adapun masyarakat di kecamatan Pedan yang telah dipilih oleh Baznas untuk mendapatkan zakat produktif dalam bentuk modal usaha berjumlah 31 orang, dengan jenis usaha dibidang bidang makanan/kuliner, asesoris/fashion, peternakan, jasa. Disini penulis akan membandingkan jumlah pendapatan mustahik sebelum menerima zakat produktif dengan setelah menerima zakat produktif dari baznas. Masyarakat yang menerima zakat produktif diantaranya dapat digambarkan sebagai berikut:

\section{Gambar 1.1}

Data Jenis UMKM

\begin{tabular}{|c|c|c|c|}
\hline No & Nama Umkm & \begin{tabular}{|c|} 
Nama \\
Pemilik \\
Umkm \\
\end{tabular} & $\begin{array}{l}\text { Harta Tahun } \\
2018\end{array}$ \\
\hline \multirow[t]{2}{*}{1} & \multicolumn{2}{|c|}{ Warung Nasi Goreng Eni } & \multirow[t]{2}{*}{ Rp.2.000.000 } \\
\hline & Bakmi & Handayani & \\
\hline 2 & Warung Soto & Atmanto & Rp. 5.000 .000 \\
\hline \multirow[t]{2}{*}{3} & \multicolumn{2}{|c|}{ Warung Minuman EsEni } & \multirow[t]{2}{*}{ Rp. 1.650 .000} \\
\hline & dan Jajanan & Nurohmah & \\
\hline 4 & Bakso Ojek & $\begin{array}{l}\text { Sri } \\
\text { Handayani }\end{array}$ & Rp. 3.500 .000 \\
\hline 5 & Bakso Ojek & Suparsih & Rp. 1.000 .000 \\
\hline 6 & Jualan Kue & Siti Rohana & Rp. 1.300 .000 \\
\hline 7 & Angkringan & Sri Fathonah & Rp. 1.500 .000 \\
\hline 8 & \multicolumn{2}{|c|}{ Warung Minuman EsJumali } & Rp. 300.000 \\
\hline 9 & Jualan Pati Onggok & Pujiono & Rp. 1.500 .000 \\
\hline 10 & Snack Kantin & Supadi & Rp. 1.000 .000 \\
\hline 11 & Jualan Pisang & $\begin{array}{l}\text { Sri Mulyani } \\
\text { Wanto }\end{array}$ & Rp. 5.000 .000 \\
\hline 12 & Jualan Pisang & Parwi & Rp. 3.000 .000 \\
\hline 13 & Jualan Kembang & Suharni & Rp. 1.000 .000 \\
\hline 14 & Bakso Bakar & Sajiman & Rp. 1.200 .000 \\
\hline 15 & $\begin{array}{l}\text { Penjual Bakmi Dan } \\
\text { Tempe }\end{array}$ & Wd. Darsiah & Rp. 1.000 .000 \\
\hline 16 & Jualan Jus dan Buah & Nur Cahyani & Rp. 2.000 .000 \\
\hline 17 & Jualan Es & $\begin{array}{l}\text { Eni } \\
\text { Susilowati }\end{array}$ & Rp. 1.500 .000 \\
\hline 18 & $\begin{array}{l}\text { Jualan Satur dan } \\
\text { Buah }\end{array}$ & Basirun & Rp. 2.000 .000 \\
\hline 19 & Jualan Sosis & Legiyem & Rp. 700.000 \\
\hline 20 & Jualan Sosis Tempe & Nur Lela & Rp. 700.000 \\
\hline 21 & Penjahit & Ngatmiyatun & Rp. 1.350 .000 \\
\hline 22 & Penjahit & $\begin{array}{l}\text { Tri } \\
\text { Sulistyowati }\end{array}$ & Rp. 1.800 .000 \\
\hline 23 & Penjahit & $\begin{array}{l}\text { Sri } \\
\text { Handayani }\end{array}$ & Rp. 1.800 .000 \\
\hline 24 & Servis Mesin Jahit & Sri Mutini & Rp. 1.700 .000 \\
\hline 25 & Ternak Ayam & $\begin{array}{l}\text { Rahmat } \\
\text { Syaiful }\end{array}$ & Rp. 750.000 \\
\hline 26 & Ternak Ayam & $\begin{array}{l}\text { Edi Agung } \\
\text { Suprapto }\end{array}$ & Rp. 200.000 \\
\hline 27 & Budidaya Jamur & \begin{tabular}{|l} 
Zuni Arto \\
Nugroho
\end{tabular} & Rp. 1.500 .000 \\
\hline 28 & Kredit Pakaian & Slamet & Rp. 10.000 .000 \\
\hline 29 & $\begin{array}{l}\text { Alumunium dan } \\
\text { Kaca }\end{array}$ & $\begin{array}{l}\text { Aditya Arif } \\
\text { Kurniawan }\end{array}$ & Rp. 5.000 .000 \\
\hline 30 & Jual Alat Tukang & Harjanto & Rp. 2.000 .000 \\
\hline 31 & Jual Obat Herbal & dian ardiani & Rp. 1.500 .000 \\
\hline
\end{tabular}




\section{Jurnal Ilmiah Ekonomi Islam, 7(01), 2021, 178}

Dari 31 pelaku UMKM tersebut penulis bagi dalam 4 (empat) kategori jenis usaha, yaitu Kelompok Makanan dan Kuliner, Kelompok Jasa, Kelompok Peternakan dan Kelompok Asesoris dan Fashion.

Adapun dalam penelitian ini penulis akan menganalisis Pendapatan Bersih UMKM setelah mendapat bantuan dari Baznas, Return atau laba bersih yang diterima mustahik tahun 2018 dan 2019, Analisis Modal Akhir Dihitung Setelah Total Lialibilitas dan Equitas Usaha UMKM, Tingkat Pertumbuhan Modal (Masyarakat Pedan) Sebelum Dan Sesudah Menerima Zakat Produktif.

\section{Pendapatan Bersih UMKM}

Laba bersih atau Nopat didapatkan UMKM setelah mengurangi antara laba sebelum pajak dikurangi dengan beban usaha. Salah satu tujuan UMKM adalah memaksimalkan nilai keuntungan usaha, sehingga sasaran rasio keuntungan diperhatikan dengan baik. Sasaran rasio keuntungan didasarkan atas preferensi keuntungan modal dan laba bersih setelah pajak. Hanya UMKM dengan tingkat kemampuan laba yang tinggi dan prospek ke depan yang cerah yang mampu membagikan dividen atau keuntungan kepada para pengusaha UMKM. Adapun perhitungannya sebagai berikut:

Tabel. 1.2

Pendapatan Bersih

\begin{tabular}{|l|l|c|c|c|}
\hline No & Nama UMKM & $\begin{array}{c}\text { Laba } \\
\text { (Rugi) } \\
\text { Usaha } \\
\text { Sebelum } \\
\text { Pajak }\end{array}$ & Beban & Nopat \\
\hline 1 & $\begin{array}{l}\text { Warung Nasi } \\
\text { Goreng Bakmi }\end{array}$ & 2.250 .000 & 120.000 & 2.130 .000 \\
\hline 2 & Warung Soto & 1.700 .000 & 100.000 & 1.600 .000 \\
\hline 3 & $\begin{array}{l}\text { Warung } \\
\text { Minuman Es dan } \\
\text { Jajanan }\end{array}$ & 1.000 .000 & 75.000 & 925.000 \\
\hline 4 & Bakso Ojek & 1.820 .000 & 140.000 & 1.680 .000 \\
\hline 5 & Bakso Ojek & 1.560 .000 & 170.000 & 1.390 .000 \\
\hline 6 & Jualan Kue & 2.340 .000 & 190.000 & 2.150 .000 \\
\hline 7 & Angkringan & 1.300 .000 & 30.000 & 1.270 .000 \\
\hline 8 & $\begin{array}{l}\text { Warung } \\
\text { Minuman Es Jus }\end{array}$ & 900.000 & 45.000 & 855.000 \\
\hline 9 & $\begin{array}{l}\text { Jualan Pati } \\
\text { Onggok }\end{array}$ & 1.500 .000 & 110.000 & 1.390 .000 \\
\hline 10 & Snack Kantin & 700.000 & 41.000 & 659.000 \\
\hline 11 & Jualan Pisang & 2.500 .000 & 160.000 & 2.340 .000 \\
\hline 12 & Jualan Pisang & 2.000 .000 & 121.000 & 1.879 .000 \\
\hline 13 & Jualan Kembang & 1.000 .000 & 100.000 & 900.000 \\
\hline
\end{tabular}

\begin{tabular}{|l|l|c|c|r|}
\hline No & Nama UMKM & $\begin{array}{c}\text { Laba } \\
\text { (Rugi) } \\
\text { Usaha } \\
\text { Sebelum } \\
\text { Pajak }\end{array}$ & Beban & Nopat \\
\hline 14 & Bakso Bakar & 3.000 .000 & 110.000 & 2.890 .000 \\
\hline 15 & $\begin{array}{l}\text { Penjual Bakmi } \\
\text { Dan Tempe }\end{array}$ & 2.000 .000 & 119.000 & 1.881 .000 \\
\hline 16 & $\begin{array}{l}\text { Jualan Jus dan } \\
\text { Buah }\end{array}$ & 2.500 .000 & 125.000 & 2.375 .000 \\
\hline 17 & Jualan Es & 2.000 .000 & 90.000 & 1.910 .000 \\
\hline 18 & $\begin{array}{l}\text { Jualan Satur dan } \\
\text { Buah }\end{array}$ & 2.000 .000 & 97.000 & 1.903 .000 \\
\hline 19 & Jualan Sosis & 1.350 .000 & 87.000 & 1.263 .000 \\
\hline 20 & $\begin{array}{l}\text { Jualan Sosis } \\
\text { Tempe }\end{array}$ & 900.000 & 35.000 & 865.000 \\
\hline 21 & Penjahit & 1.200 .000 & 75.000 & 1.125 .000 \\
\hline 22 & Penjahit & 1.000 .000 & 35.000 & 965.000 \\
\hline 23 & Penjahit & 1.200 .000 & 90.000 & 1.110 .000 \\
\hline 24 & $\begin{array}{l}\text { Servis Mesin } \\
\text { Jahit }\end{array}$ & 1.200 .000 & 30.000 & 1.170 .000 \\
\hline 25 & Ternak Ayam & 900.000 & 35.000 & 865.000 \\
\hline 26 & Ternak Ayam & 700.000 & 30.000 & 670.000 \\
\hline 27 & Budidaya Jamur & 1.200 .000 & 25.000 & 1.175 .000 \\
\hline 28 & Kredit Pakaian & 1.500 .000 & 45.000 & 1.455 .000 \\
\hline 29 & $\begin{array}{l}\text { Alumunium dan } \\
\text { Kaca }\end{array}$ & 900.000 & 30.000 & 870.000 \\
\hline 30 & Jual Alat Tukang & 2.200 .000 & 110.000 & 2.090 .000 \\
\hline 31 & Jual Obat Herbal & 900.000 & 45.000 & 855.000 \\
\hline
\end{tabular}

Berdasarkan Tabel 1.2 di atas dapat dijelaskan bahwa nopat atau laba bersih masing-masing UMKM sebagai berikut, Warung Nasi Goreng Bakmi sebesar 2.130.000, Warung Soto Sebesar 1.600.000, Warung Minuman Es sebesar 925.000, Bakso Ojek sebesar 1.680.000, Bakso Ojek sebesar 1.390.000, Jualan Kue sebesar 2.150.000, Angkringan sebesar 1.270.000, Warung Minuman Jus sebesar 855.000, Jualan pati Onggok sebesar 1.390.000, Kantin sebesar 659.000, Jualan Pisang 2.340.000, Jualan Pisang sebesar 1.879.000, Jualan Kembang sebesar 900.000, Bakso Bakar sebesar 2.890.000, Penjual Bakmi dan Tempe sebesar 1.881.000, Jualan Jus dan Buah sebesar 2.375.000, Jualan Es sebesar sebesar 1.910.000, Jualan Satur dan Buah sebesar 1.903.000, Jualan Sosis sebesar 1.263.000, Jualan Sosis Tempe 865.000, Penjahit sebesar 1.125.000, Penjahit sebesar 965.000, Servis Mesin Jahit sebesar 1.170.000, Ternak Ayam sebesar 865.000, Ternak Ayam sebesar 670.000, Budidaya Jamur 1.175.000, Kredit Pakaian Sebesar 1.455.000, Alumunium Kaca sebesar 870.000, Jual 
Jurnal Ilmiah Ekonomi Islam, 7(01), 2021, 179

Alat Tukang sebesar 2.090.000, Jual Alat Herbal sebesar 855.000.

Dari data tersebut dapat disimpulkan bahwa masing-masing UMKM mendapatkan keuntungan bersih diatas $50 \%$ dari modal awal melakukan kegiatan usahanya. Banyak UMKM yang selalu mengomunikasikan bahwa UMKM memiliki prospektif dalam menghadapi masalah keuangan sudah tentu akan mengalami kesulitan dalam membagi keuntungan. Hal ini berdampak pada UMKM yang mampu membagikan keuntungan, memberikan sinyal pada pasar bahwa UMKM tersebut memiliki prospek ke depan yang cerah dan mampu mempertahankan tingkat keuntungan yang telah ditetapkan pada periode sebelumnya.

\section{Analisis Return UMKM Periode 2018-2019}

Return dalam istilah ekonomi merupakan penghasilan (gain) atau kerugian (loss) karena turunnya investasi pada suatu periode tertentu. Perubahan Return usaha lebih dipengaruhi oleh perubahan harga jual usaha dan jasa. Apabila harga jual usaha dan jasa mengalami kenaikan, maka Return usaha yang diterima oleh pemilik UMKM juga cenderung naik. Perhitungan Return Usaha dalam penelitian ini menggunakan data yang diperoleh dari data UMKM setiap akhir periode. Sedangkan perubahan Return Usaha tidak beriringan dengan modal awal UMKM.

Tabel 1.3

Return UMKM

\begin{tabular}{|c|l|c|c|c|}
\hline No & Nama UMKM & \multicolumn{2}{l}{ Total Harta UMKM } & $\begin{array}{c}\text { Return } \\
\text { UMKM }\end{array}$ \\
\cline { 3 - 5 } & & $\mathbf{2 0 1 8}$ & $\mathbf{2 0 1 9}$ & $\mathbf{2 0 1 9}$ \\
\hline 1 & $\begin{array}{l}\text { Warung Nasi } \\
\text { Goreng Bakmi }\end{array}$ & 2.000 .000 & 4.329 .400 & 2.250 .000 \\
\hline 2 & Warung Soto & 5.000 .000 & 6.512 .000 & 1.700 .000 \\
\hline 3 & $\begin{array}{l}\text { Warung } \\
\text { Minuman Es dan }\end{array}$ & 1.650 .000 & 2.501 .400 & 1.000 .000 \\
\hline 4 & Jajanan & & & \\
\hline 5 & Bakso Ojek & 3.500 .000 & 4.854 .000 & 1.820 .000 \\
\hline 6 & Jualan Kue & 1.300 .000 & 3.792 .000 & 2.340 .000 \\
\hline 7 & Angkringan & 1.500 .000 & 1.750 .000 & 1.300 .000 \\
\hline 8 & $\begin{array}{l}\text { Warung } \\
\text { Minuman Es Jus }\end{array}$ & 300.000 & 1.314 .000 & 900.000 \\
\hline 9 & $\begin{array}{l}\text { Jualan Pati } \\
\text { Onggok }\end{array}$ & 1.500 .000 & 2.000 .000 & 1.500 .000 \\
\hline 10 & Snack Kantin & 1.000 .000 & 1.350 .000 & 700.000 \\
\hline 11 & Jualan Pisang & 5.000 .000 & 6.695 .000 & 2.500 .000 \\
\hline 12 & Jualan Pisang & 3.000 .000 & 5.974 .000 & 2.000 .000 \\
\hline 13 & Jualan Kembang & 1.000 .000 & 5.350 .000 & 1.000 .000 \\
\hline & & & & \\
\hline
\end{tabular}

\begin{tabular}{|c|c|c|c|c|}
\hline \multirow[t]{2}{*}{ No } & \multirow[t]{2}{*}{ Nama UMKM } & \multicolumn{2}{|c|}{ Total Harta UMKM } & \multirow{2}{*}{$\begin{array}{c}\begin{array}{c}\text { Return } \\
\text { UMKM }\end{array} \\
2019\end{array}$} \\
\hline & & 2018 & 2019 & \\
\hline 14 & Bakso Bakar & 1.200 .000 & 5.550 .000 & 3.000 .000 \\
\hline 15 & $\begin{array}{l}\text { Penjual Bakmi } \\
\text { Dan Tempe }\end{array}$ & 1.000 .000 & 1.250 .000 & 2.000 .000 \\
\hline 16 & $\begin{array}{l}\text { Jualan Jus dan } \\
\text { Buah }\end{array}$ & 2.000 .000 & 3.000 .000 & 2.500 .00 \\
\hline 17 & Jualan Es & 1.500 .000 & 2.157 .200 & 2.000 .000 \\
\hline 18 & $\begin{array}{l}\text { Jualan Satur dan } \\
\text { Buah }\end{array}$ & 2.000 .000 & 6.350 .000 & 2.000 .000 \\
\hline 19 & Jualan Sosis & 700.000 & 5.050 .000 & 1.350 .000 \\
\hline 20 & $\begin{array}{l}\text { Jualan Sosis } \\
\text { Tempe }\end{array}$ & 700.000 & 1.200 .000 & 900.000 \\
\hline 21 & Penjahit & 1.350 .000 & 3.460 .000 & 1.200 .000 \\
\hline 22 & Penjahit & 1.800 .000 & 4.350 .000 & 1.000 .000 \\
\hline 23 & Penjahit & 1.800 .000 & 4.350 .000 & 1.200 .000 \\
\hline 24 & $\begin{array}{l}\text { Servis Mesin } \\
\text { Jahit }\end{array}$ & 1.700 .000 & 3.789 .000 & 1.200 .000 \\
\hline 25 & Ternak Ayam & 750.000 & 1.744 .000 & 900.000 \\
\hline 26 & Ternak Ayam & 200.000 & 2.066 .000 & 700.000 \\
\hline 27 & Budidaya Jamur & 1.500 .000 & 2.158 .400 & 1.200 .000 \\
\hline 28 & Kredit Pakaian & 10.000 .000 & 11.000 .000 & 1.500 .000 \\
\hline 29 & $\begin{array}{l}\text { Alumunium dan } \\
\text { Kaca }\end{array}$ & 5.000 .000 & 5.500 .000 & 900.000 \\
\hline 30 & Jual Alat Tukang & 2.000 .000 & 2.500 .000 & 2.200 .000 \\
\hline 31 & Jual Obat Herbal & 1.500 .000 & 2.340 .000 & 900.000 \\
\hline
\end{tabular}

Dari Tabel 1.3 diatas dapat diketahui return yang didapatkan masing-masing pemilik UMKM sebagai berikut Warung Nasi Goreng Bakmi sebesar 2.250.000, Warung Soto Sebesar 1.700.000, Warung Minuman Es sebesar 1.000.000, Bakso Ojek sebesar 1.820.000, Bakso Ojek sebesar 1.560.000, Jualan Kue sebesar 2.340.000, Angkringan sebesar 1.300.000, Warung Minuman Jus sebesar 900.000, Jualan pati Onggok sebesar 1.500.000, Kantin sebesar 700.000, Jualan Pisang 2.500.000, Jualan Pisang sebesar 2.000.000, Jualan Kembang sebesar 1.000.000, Bakso Bakar sebesar 3.000.000, Penjual Bakmi dan Tempe sebesar 2.000.000, Jualan Jus dan Buah sebesar 2.500.000, Jualan Es sebesar sebesar 2.000.000, Jualan Satur dan Buah sebesar 2.000.000, Jualan Sosis sebesar 1.350.000, Jualan Sosis Tempe 900.000, Penjahit sebesar 1.200.000, Penjahit sebesar 1.000.000, Servis Mesin Jahit sebesar 1.200.000, Ternak Ayam sebesar 900.000, Ternak Ayam sebesar 700.000, Budidaya Jamur 1.200.000, Kredit Pakaian Sebesar 1.500.000, Alumunium Kaca sebesar 900.000, Jual Alat Tukang sebesar 2.200.000, Jual Alat Herbal sebesar 900.000 . 
Dari data tersebut dapat disimpulkan bahwa masing-masing UMKM mengalami kenaikan Modal. Modal dihitung dari total besarnya harta UMKM tahun 2019 dikurangi total harta UMKM tahun 2018. Adanya keuntungan berkala yang diperoleh UMKM akan memberikan pandangan positif pada UMKM. Pandangan positif tersebut muncul karena keuntungan yang diperoleh selama satu tahun dapat dibagikan kepada pemilik UMKM. Dengan demikian jumlah keuntungan akan meningkat dan selanjutnya akan berpengaruh terhadap Return usaha yang diperoleh selama periode 1 tahun.

Selama tahun penelitian telah terjadi ketidakstabilan ekonomi di Indonesia. Persoalan yang dianggap mengganggu laju pertumbuhan ekonomi terutama UMKM yaitu masalah permodalan yang sulit dan dianggap meresahkan UMKM. Berdasarkan data yang telah diolah dengan adanya bantuan dari Baznas, UMKM mengalami kenaikan return usaha yang signifikan dan sangat baik

\section{Analisis Modal Akhir Dihitung Setelah Total Lialibilitas dan Equitas Usaha UMKM}

Liabilitas adalah hutang yang harus dilunasi atau pelayanan yang harus dilakukan pada masa datang pada pihak lain. Dalam perhitungan ini penulis melihat pendapatan bersih pelaku UMKM setelah dipotong kewajiban. Sedangkan Ekuitas merupakan selisih antara nilai aset dengan liabilitas. Dengan kata lain, ekuitas merupakan hak residual yang dimiliki atas aset perusahaan setelah dikurangi dengan liabilitas. Aset merupakan sesuatu yang dimiliki, misalnya pelaku UMKM memiliki meja, kursi, perabotan usaha dan lain sebagainya. Untuk mengetahui nilai ekuitas yang dimiliki, sebaiknya pelaku UMKM mengatur nilai ekuitasnya dengan baik. Nilai ini dapat dihitung dengan mencatat semua asset liabilitas yang dimiliki. Supaya mendapat keuntungan dan tidak devisit, sebaiknya memang nilai ekuitas positif, atau liabilitasnya lebih kecil daripada nilai asetnya.

Untuk mengetahui Modal Akhir UMKM dapat dihitung dengan menjumlahkan antara Liabilitas atau Utang dengan total Equitas atau nilai UMKM saat ini pada tahun tersebut.
Tabel 1.4

Modal Akhir UMKM

\begin{tabular}{|c|c|c|c|c|}
\hline No & Nama UMKM & $\begin{array}{c}\text { Total } \\
\text { Liabilitas }\end{array}$ & Equitas & $\begin{array}{l}\text { Modal } \\
\text { Akhir }\end{array}$ \\
\hline 1 & $\begin{array}{l}\text { Warung Nasi } \\
\text { Goreng Bakmi }\end{array}$ & 2.670 .600 & 1.658 .800 & 4.329 .400 \\
\hline 2 & Warung Soto & 3.488 .000 & 3.064 .000 & 6.512 .000 \\
\hline 3 & $\begin{array}{l}\text { Warung } \\
\text { Minuman Es dan } \\
\text { Jajanan }\end{array}$ & 2.498 .000 & 3.400 .000 & 2.501 .400 \\
\hline 4 & Bakso Ojek & 3.646 .000 & 1.208 .000 & 4.854 .000 \\
\hline 5 & Bakso Ojek & 3.388 .000 & $(-777.400)$ & 2.611 .400 \\
\hline 6 & Jualan Kue & 2.508 .000 & 1.284 .000 & 3.792 .000 \\
\hline 7 & Angkringan & 4.750 .000 & $(-3.000 .000)$ & 1.750 .000 \\
\hline 8 & $\begin{array}{l}\text { Warung } \\
\text { Minuman Es Jus }\end{array}$ & 3.986 .000 & $(-2.672 .000)$ & 1.314 .000 \\
\hline 9 & $\begin{array}{l}\text { Jualan Pati } \\
\text { Onggok }\end{array}$ & 4.500 .000 & $(-2.500 .000)$ & 2.000 .000 \\
\hline 10 & Snack Kantin & 4.650 .000 & $(-3.300 .000)$ & 1.350 .000 \\
\hline 11 & Jualan Pisang & 3.305 .000 & 3.390 .000 & 6.695 .000 \\
\hline 12 & Jualan Pisang & 2.026 .000 & 3.948 .000 & 5.974 .000 \\
\hline 13 & Jualan Kembang & 650.000 & 4.700 .000 & 5.350 .000 \\
\hline 14 & Bakso Bakar & 650.000 & 4.900 .000 & 5.550 .000 \\
\hline 15 & $\begin{array}{l}\text { Penjual Bakmi } \\
\text { Dan Tempe }\end{array}$ & 4.750 .000 & $(-3.500 .000)$ & 1.250 .000 \\
\hline 16 & $\begin{array}{l}\text { Jualan Jus dan } \\
\text { Buah }\end{array}$ & 4.000 .000 & $(-1.000 .000)$ & 3.000 .000 \\
\hline 17 & Jualan Es & 2.842 .800 & $(-685.600)$ & 2.157 .200 \\
\hline 18 & $\begin{array}{l}\text { Jualan Satur dan } \\
\text { Buah }\end{array}$ & 650.000 & 5.700 .000 & 6.350 .000 \\
\hline 19 & Jualan Sosis & 650.000 & 4.400 .000 & 5.050 .000 \\
\hline 20 & $\begin{array}{l}\text { Jualan Sosis } \\
\text { Tempe }\end{array}$ & 4.500 .000 & $(-3.300 .000)$ & 1.200 .000 \\
\hline 21 & Penjahit & 2.890 .000 & 570.000 & 3.460 .000 \\
\hline 22 & Penjahit & 650.000 & 3.700 .000 & 4.350 .000 \\
\hline 23 & Penjahit & 650.000 & 3.700 .000 & 4.350 .000 \\
\hline 24 & $\begin{array}{l}\text { Servis Mesin } \\
\text { Jahit }\end{array}$ & 2.910 .000 & 879.000 & 3.789 .000 \\
\hline 25 & Ternak Ayam & 3.255 .000 & $(-1.511 .000)$ & 1.744 .000 \\
\hline 26 & Ternak Ayam & 2.934 .000 & $(-868.000)$ & 2.066 .000 \\
\hline 27 & Budidaya Jamur & 2.841 .600 & $(-683.200)$ & 2.158 .400 \\
\hline 28 & Kredit Pakaian & 4.000 .000 & 7.000 .000 & 11.000 .000 \\
\hline 29 & $\begin{array}{l}\text { Alumunium dan } \\
\text { Kaca }\end{array}$ & 4.500 .000 & 1.000 .000 & 5.500 .000 \\
\hline 30 & Jual Alat Tukang & 4.500 .000 & $(-2.000 .000)$ & 2.500 .000 \\
\hline 31 & Jual Obat Herbal & 3.750 .000 & $(-1.410 .000)$ & 2.340 .000 \\
\hline
\end{tabular}

Dari Tabel 1.4 diatas dapat diketahui Modal Akhir yang didapatkan masing-masing pemilik UMKM sebagai berikut, Warung Nasi Goreng Bakmi sebesar 4.329.400, Warung Soto Sebesar 6.512.000, Warung Minuman Es sebesar 2.501.400, Bakso Ojek sebesar 4.584.000, Bakso Ojek sebesar 2.611.400, 
Jualan Kue sebesar 3.792.000, Angkringan sebesar 1.750.000, Warung Minuman Jus sebesar 1.314.000, Jualan pati Onggok sebesar 2.000.000, Kantin sebesar 1.350.000, Jualan Pisang 6.695.000, Jualan Pisang sebesar 5.974.000, Jualan Kembang sebesar 5.350.000, Bakso Bakar sebesar 5.550.000, Penjual Bakmi dan Tempe sebesar 1.250.000, Jualan Jus dan Buah sebesar 3.000.000, Jualan Es sebesar sebesar 2.157.200, Jualan Satur dan Buah sebesar 6.350.000, Jualan Sosis sebesar 5.050.000, Jualan Sosis Tempe 1.200.000, Penjahit sebesar 3.460.000, Penjahit sebesar 4.350.000, Servis Mesin Jahit sebesar 3.789.000, Ternak Ayam sebesar 1.744.000, Ternak Ayam sebesar 2.066.000, Budidaya Jamur 2.158.400, Kredit Pakaian Sebesar 11.000.000, Alumunium Kaca sebesar 5.500.000, Jual Alat Tukang sebesar 2.500.000, Jual Alat Herbal sebesar 2.340.000.

Dari tabel 1.4 tersebut dapat ditarik kesimpulan bahwa utang atau lialibilitas sebuah UMKM mempengaruhi modal akhir yang akan dimiliki UMKM saat ini, sementara Equitas UMKM harus selalu diperhatikan, Equitas UMKM saat ini sangat mempengaruhi nilai Equitas UMKM dimasa yang akan datang. Setelah melihat dan menimbang modal akhir yang diperoleh setiap UMKM dapat diambil kesimpulan bahwa UMKM-UMKM tersebut memiliki prospek, kualitas untuk bersaing di masa yang akan datang.

\section{Efektifitas Pendayagunaan Zakat Produktif} (Dilihat Dari Tingkat Pertumbuhan Modal (Masyarakat Pedan) Sebelum Dan Sesudah Menerima Zakat Produktif).

Efektivitas Berasal dari kata efektif yang berarti ada efek (pengaruh), membawa hasil, berhasil guna (Departemen Pendidikan dan Kebudayaan, 1990: 219). Efektivitas adalah tingkat dimana kinerja yang sesungguhnya sebanding dengan kinerja yang ditargetkan (Sumardji, 2006: 269). Menurut Subagyo (2000) efektivitas adalah kesesuaian antara output dengan tujuan yang ditetapkan. Efektivitas adalah suatu keadaan yang terjadi karena dikehendaki.

Adapun tujuan akhir dari diberikannya zakat produktif adalah untuk melihat efektivitas atau keberhasilan zakat produktif dalam meningkatkan jumlah pendapatan para mustahik pelaku UMKM.
Tabel 1.5

Tingkat Pertumbuhan Modal

\begin{tabular}{|c|c|c|c|c|}
\hline no & nama umkm & $\begin{array}{c}\text { modal } \\
\text { awal }\end{array}$ & $\begin{array}{l}\text { modal } \\
\text { akhir }\end{array}$ & $\begin{array}{c}\text { tingkat } \\
\text { pertumb } \\
\text { uhan } \\
\end{array}$ \\
\hline 1 & $\begin{array}{l}\text { Warung Nasi } \\
\text { Goreng Bakmi }\end{array}$ & 2.000 .000 & 4.329 .400 & $116.47 \%$ \\
\hline 2 & Warung Soto & 5.000 .000 & 6.512 .000 & $30.24 \%$ \\
\hline 3 & $\begin{array}{l}\text { Warung } \\
\text { Minuman Es dan } \\
\text { Jajanan }\end{array}$ & 1.650 .000 & 2.501 .400 & $51.6 \%$ \\
\hline 4 & Bakso Ojek & 3.500 .000 & 4.854 .000 & $38.69 \%$ \\
\hline 5 & Bakso Ojek & 1.000 .000 & 2.611 .400 & $161.14 \%$ \\
\hline 6 & Jualan Kue & 1.300 .000 & 3.792 .000 & $191.69 \%$ \\
\hline 7 & Angkringan & 1.500 .000 & 1.750 .000 & $16.66 \%$ \\
\hline 8 & $\begin{array}{l}\text { Warung } \\
\text { Minuman Es Jus }\end{array}$ & 300.000 & 1.314 .000 & $33,8 \%$ \\
\hline 9 & $\begin{array}{l}\text { Jualan Pati } \\
\text { Onggok }\end{array}$ & 1.500 .000 & 2.000 .000 & $33.33 \%$ \\
\hline 10 & Snack Kantin & 1.000 .000 & 1.350 .000 & $35 \%$ \\
\hline 11 & Jualan Pisang & 5.000 .000 & 6.695 .000 & $33.9 \%$ \\
\hline 12 & Jualan Pisang & 3.000 .000 & 5.974 .000 & $99.13 \%$ \\
\hline 13 & Jualan Kembang & 1.000 .000 & 5.350 .000 & $435 \%$ \\
\hline 14 & Bakso Bakar & 1.200 .000 & 5.550 .000 & $358.33 \%$ \\
\hline 15 & $\begin{array}{l}\text { Penjual Bakmi } \\
\text { Dan Tempe }\end{array}$ & 1.000 .000 & 1.250 .000 & $25 \%$ \\
\hline 16 & $\begin{array}{l}\text { Jualan Jus dan } \\
\text { Buah }\end{array}$ & 2.000 .000 & 3.000 .000 & $50 \%$ \\
\hline 17 & Jualan Es & 1.500 .000 & 2.157 .200 & $43.81 \%$ \\
\hline 18 & $\begin{array}{l}\text { Jualan Satur dan } \\
\text { Buah }\end{array}$ & 2.000 .000 & 6.350 .000 & $217.5 \%$ \\
\hline 19 & Jualan Sosis & 700.000 & 5.050 .000 & $621.43 \%$ \\
\hline 20 & $\begin{array}{l}\text { Jualan Sosis } \\
\text { Tempe }\end{array}$ & 700.000 & 1.200 .000 & $71.43 \%$ \\
\hline 21 & Penjahit & 1.350 .000 & 3.460 .000 & $156.29 \%$ \\
\hline 22 & Penjahit & 1.800 .000 & 4.350 .000 & $141.66 \%$ \\
\hline 23 & Penjahit & 1.800 .000 & 4.350 .000 & $141.66 \%$ \\
\hline 24 & $\begin{array}{l}\text { Servis Mesin } \\
\text { Jahit }\end{array}$ & 1.700 .000 & 3.789 .000 & $122.88 \%$ \\
\hline 25 & Ternak Ayam & 750.000 & 1.744 .000 & $132.53 \%$ \\
\hline 26 & Ternak Ayam & 200.000 & 2.066 .000 & $933 \%$ \\
\hline 27 & Budidaya Jamur & 1.500 .000 & 2.158 .400 & $43.89 \%$ \\
\hline 28 & Kredit Pakaian & 10.000 .000 & 11.000 .000 & $10 \%$ \\
\hline 29 & $\begin{array}{l}\text { Alumunium dan } \\
\text { Kaca }\end{array}$ & 5.000 .000 & 5.500 .000 & $10 \%$ \\
\hline 30 & Jual Alat Tukang & 2.000 .000 & 2.500 .000 & $25 \%$ \\
\hline 31 & Jual Obat Herbal & 1.500 .000 & 2.340 .000 & $56 \%$ \\
\hline
\end{tabular}

Dari Tabel 1.5 diatas dapat diketahui efektifitas yang didapatkan masing-masing pemilik UMKM setelah menerima zakat produktif sebagai berikut, Warung Nasi Goreng Bakmi sebesar 116.47\%, Warung Soto Sebesar 30.24\%, Warung Minuman Es 


\section{Jurnal Ilmiah Ekonomi Islam, 7(01), 2021, 182}

sebesar 51.6\%, Bakso Ojek sebesar 38.69\%, Bakso Ojek sebesar 161.14\%, Jualan Kue sebesar 191.69\%, Angkringan sebesar 16.66\%, Warung Minuman Jus sebesar 33,8\%, Jualan pati Onggok sebesar 33.33\%, Kantin sebesar $35 \%$, Jualan Pisang 33.9\%, Jualan Pisang sebesar 99.13\%, Jualan Kembang sebesar 435\%, Bakso Bakar sebesar 358.33\%, Penjual Bakmi dan Tempe sebesar 25\%, Jualan Jus dan Buah sebesar 50\%, Jualan Es sebesar sebesar 43.81\%, Jualan Satur dan Buah sebesar 217.5\%, Jualan Sosis sebesar $621.43 \%$, Jualan Sosis Tempe $71.43 \%$, Penjahit sebesar $156.29 \%$, Penjahit sebesar $141.66 \%$, Servis Mesin Jahit sebesar 122.88\%, Ternak Ayam sebesar 43.89\%, Ternak Ayam sebesar 132.53\%, Budidaya Jamur 43.89\%, Kredit Pakaian Sebesar 10\%, Alumunium Kaca sebesar 10\%, Jual Alat Tukang sebesar 25\%, Jual Alat Herbal sebesar 56\%.

Dari Tabel 1.5 diatas dapat disimpulkan bahwa presentase pertumbuhan diatas 50\% setelah menerima zakat produktif. Presentase tersebut dapat diketahui dari pengurangan antara Modal Akhir dikurangi Modal Awal dibagi Modal Awal dan dikalikan 100\%. Kerjasama yang dijalin Baznas memberikan dampak yang positif bagi para pemilik UMKM. Para pemilik UMKM merasa terbantu dengan adanya program Zakat Produktif dari Baznas. Baznas memberikan bantuan zakat produktif untuk pengembangan usaha yang dirintis oleh pemilik UMKM sehingga diharapkan adanya peningkatan kesejahteraan hidup. Bentuk kerjasama yang dijalin oleh Baznas seperti di atas terbukti telah memberikan banyak manfaat, khususnya dalam hal peningkatan ekonomi. Oleh karena itu diharapkan Baznas untuk dapat bekerjasama dengan lembaga/organisasi kemasyarakatan lainnya yang membutuhkan bantuan untuk peningkatan ekonomi. Selain itu Baznas juga diharapkan untuk lebih giat lagi menyebarluaskan informasi mengenai program zakat produktif tersebut, sebab program ini sangat bagus, ditujukan untuk kegiatan usaha produktif sehingga tidak langsung habis dipakai, memberikan manfaat yang berkesinambungan dan mendorong penerimanya untuk selalu berusaha.

\section{KESIMPULAN}

Berdasarkan hasil penelitian yang dilakukan, dapat diketahui bahwa Pemberian zakat produktif berupa modal usaha oleh Baznas kepada mustahik pelaku UMKM di Kecamatan Pedan Kabupaten Klaten telah memberikan dampak positif bagi perekonomian mereka. Hal ini terlihat dari jumlah pendapatan mustahik yang mengalami peningkatan setelah menerima zakat produktif dari Baznas.

\section{DAFTAR PUSTAKA}

Asnaini. (2008). Zakat Produktif dalam Perspektif Hukum Islam. Yogyakarta: Pustaka Belajar.

Edwin, M. (2007). Pengenalan Eksklusif Islam. Jakarta: Kencana.

Hafihuddin, D. (2007). The Power of Zakat Studi Perbandingan Pengelolaan Zakat Asia Tenggara. Malang: UIN Malang Press.

Indonesia, D. E.-B. (2016). Pengelolaan Zakat Yang Efektif : Konsep Dan Praktik Di Beberapa Negara. Jakarta: Departemen Ekonomi Dan Keuangan Syariah - Bank Indonesia.

Pratama, Y. C. (2015). Peran Zakat Dalam Penanggulangan Kemiskinan (Studi Kasus: Program Zakat Produktif Pada Badan Amil Zakat Nasional). The Journal of Tauhidinomics, Vol. 1 No. 1 Uin Syarif Hidayatullah, 95.

Qadir, A. (1998). Zakat Dalam Dimensi Mahdhah dan Sosial. Jakarta: Raja Grafindo.

Qardhawi, Y. (2002). Hukum Zakat. Jakarta: PT. Litera Antar Nusa.

Raharjo, M. D. (1999). Islam dan Transformasi Sosial Ekonomi. Jakarta: Lembaga Studi Agama dan Filsafat.

Sari, D. P. (2013). Telisik Perlakuan Teori Entitas Usaha Mikro, Kecil dan Menengah. Jurnal Akuntansi Multiparadigma, 4, 191.

Statistik, B. P. (2019).

Sumardji. (2006). Kamus Ekonomi. Jakarta: Wipress. 